\title{
The investigation of miR-499 in apoptosis of cardiomyocytes in blood serum of MI patients
}

\author{
Hesam Hasanzadeh ${ }^{1}$, Changiz Ahmadizadeh ${ }^{2}$, Abolfazl Ghorbani ${ }^{3}$ \\ ${ }^{1}$ MSc, Department of Molecular Genetics, Ahar Branch, Islamic Azad University, Ahar, Iran \\ ${ }^{2}$ Assistant Professor, Department of Microbiology, Ahar Branch, Islamic Azad University, Ahar, Iran \\ ${ }^{3}$ Assistant Professor, Department of Genetics, Shabestar Branch, Islamic Azad University, Shabestar, Iran
}

\begin{abstract}
Background: Ischemic heart diseases (IHD) cause most deaths worldwide in a way that they are the cause of more than 30 percent of the deaths. After the discovery of miRNA in 1990 and the discovery of more than 2500 types of miRNA, gradually the importance of these mechanism regulators and molecular signals and gene routes were identified in the processes and the cellular mechanisms, especially in cardiovascular system. The goal of this research was to investigate miR-499 dominating the apoptosis of heart cellules in serums of the patients with MI (myocardial infarction).

Materials and methods: In this case-control study, miR-499 were investigated by real time PCR among 70 MI patients in Shahid Madani Hospital in Tabriz in 2017 and the data were compared with healthy persons. The statistical analyses were carried out using SPSS (version19) by t-test method. $\mathrm{P}<0.05$ were considered as significant.

Results: The expression levels of miR-499 significantly increased among MI patients compared to control group ( $\mathrm{P}=0.007)$. The miR-499 expression has no significant difference between overweight and normal weight people $(\mathrm{P}=0.06)$.

Conclusion: The present study showed that the expression of miR-499 among individuals suffering from MI has been greater than healthy people and it can be utilized as a diagnostic and also prognostic factor of MI patients.
\end{abstract}

Keywords: Acute myocardial infarction, Apoptosis, miR-499.

Cited as: Hasanzadeh H, Ahmadizadeh CH, Ghorbani A. The investigation of miR-499 in apoptosis of cardiomyocytes in blood serum of MI patients. Medical Science Journal of Islamic Azad University, Tehran Medical Branch 2019; 29(2): 155-162.

Correspondence to: Changiz Ahmadizadeh

Tel: +989104030464

E-mail: ch-ahmadizadeh@iau-ahar.ac.ir

ORCID ID: 0000-0003-0780-3159

Received: 8 Sep 2018; Accepted: 27 Nov 2018 
مجله علوم يزشكى دانشعاه آزاد اسلامى

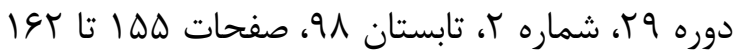

\title{
MI MiR-499 دخيل در روند آيويتوز سلول هاى قلب درسرم بيماران دجار
}

\author{
حسام حسن زاده'، جنغَيز احمدى زاده'، ابوالفضل قربانى
}

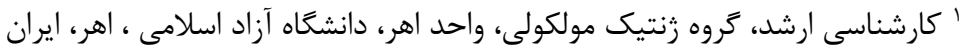

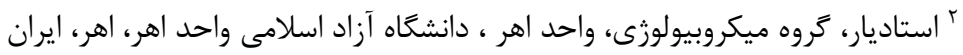

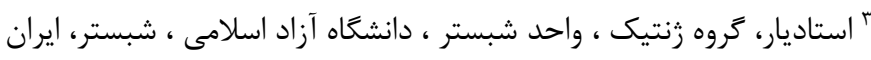

جكيده

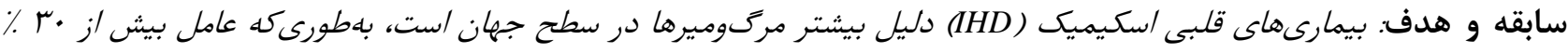

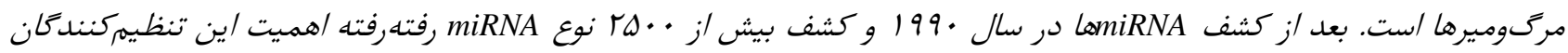

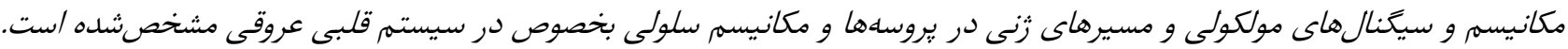

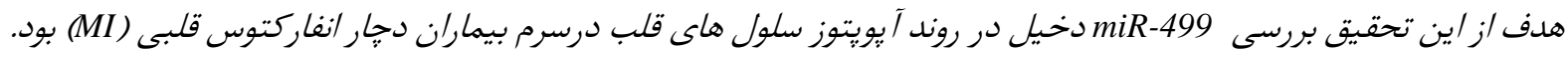

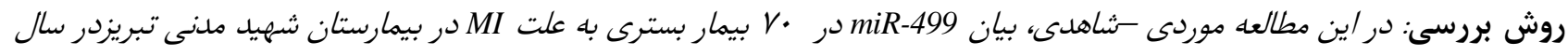

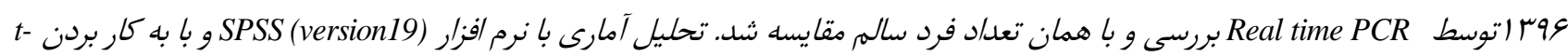

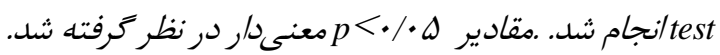

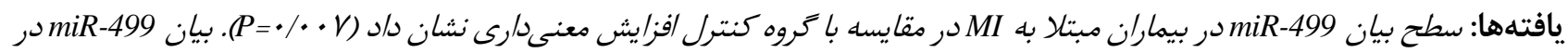

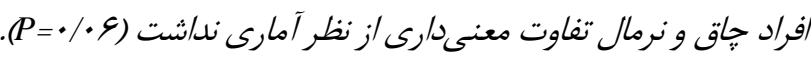

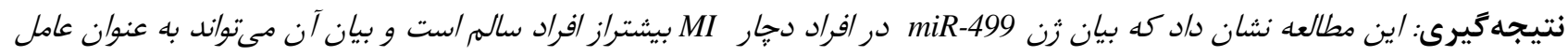

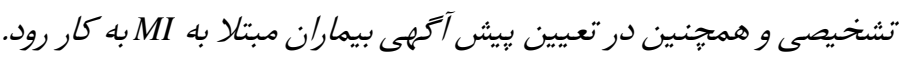

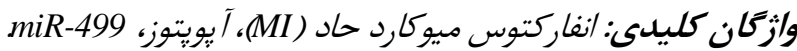

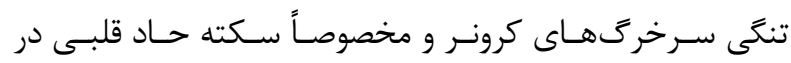
مقله

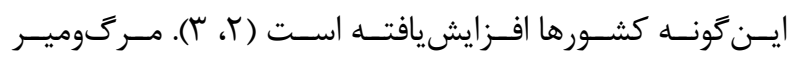
بيمارىهاى قلبى -عروقى در كشورهاى توسعهيافته روبه كاهش نهاده، ولى در كشورهاى درحال توسعه و همجنين ايران به دليـل

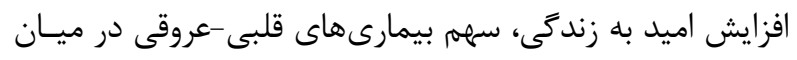

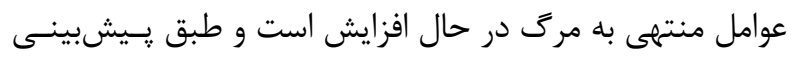

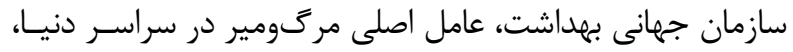

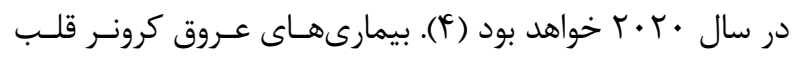

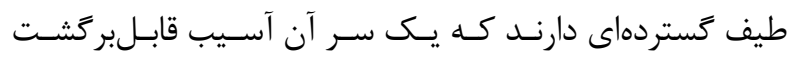

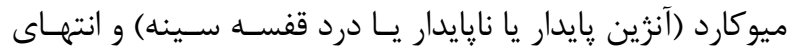

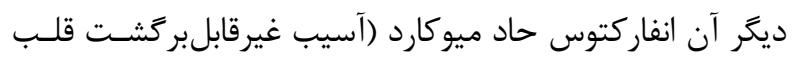

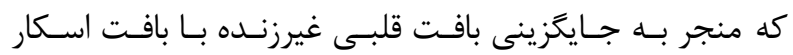
بيمارىهاى قلبى و عروقى شايعترين علـت مـركَّوميــر در اكثـر

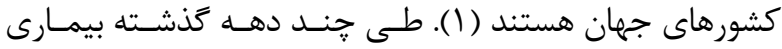

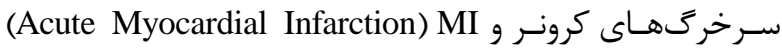

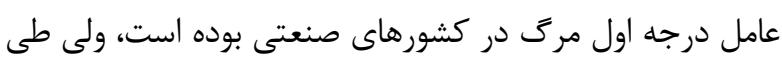

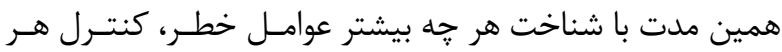

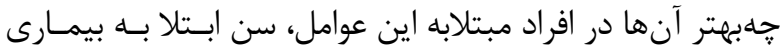

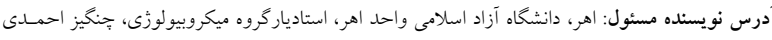

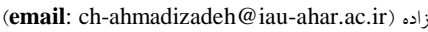 ORCID ID: 0000-0003-0076-2446 تاريخ دريافت مقاله: 9V/9/IV تاريخ بذيرش مقاله: 9V/9/9 
تبريز، در محدوده سنى •و-•r سـال در سـال عوسا در صـورت

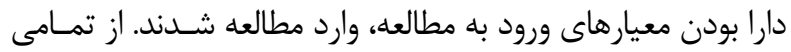
شركت كنند

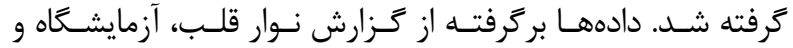

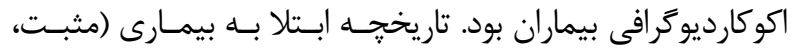
منفى)، دريافت دارويى، سابقه جراحى و و فعاليـت بــنى (فعاليـت

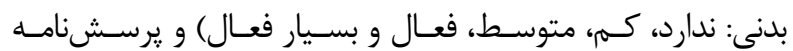

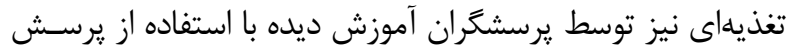

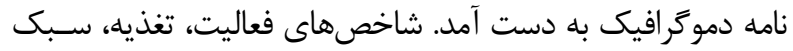

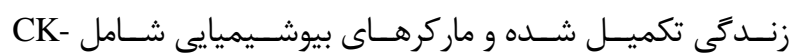

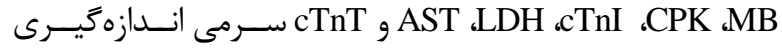
شد؛ سيس ارتباط بـين 499-miR و متغيرهـاى تغذيـهاى، سـبك زندگى، ماركرهاى بيوشيميايى و شدت بيمارى تحليل شد. بعـد از تحويل خون به مقدار ه ميلى ليتر از هر فرد به صـورت محيطى مسئى

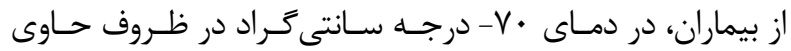

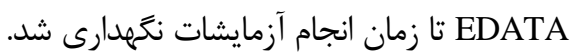

\section{Micro-RNA روش استخراج}

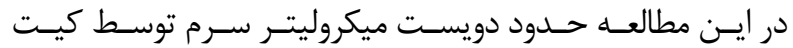
اختصاصـى جداسـازى و اسـتخراج microRNAهــا بــا اســفاده از miRCURY RNA isolation kit از شركت آزيكون انجام شـد. براى تعيين غلظت RNA از دستخاه نانودراب استفاده شد و اساس كار اين دستخاه اسيكتروفتومترى بود كه سرعت و دقت بـالايى در

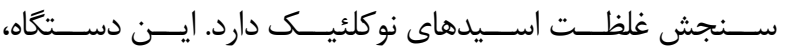

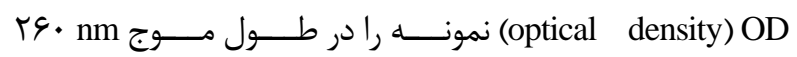
براى تعيين غلظت RNA اندازه كيرى كرد. هر واحد OD در طـول موج nm • ع برابر با RNA j40 ng/ml تك رشتهاى است.

سنتز سن

بـراى سـنتز micro RNA cDNA از كيـت شـركت Exiqon استفاده شـد. دسـتور العمل ايـن شـركت شـامل r مرحلـه اسـت. مرحله اول شـامل اضـافه كـردن poly A و مرحلـه دوم reverse transcription

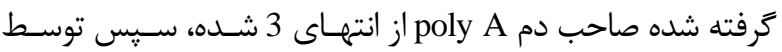
يرايمر مخصوص كيت از تمام RNA هاى كوجى cDNA سـاخته

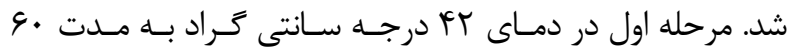

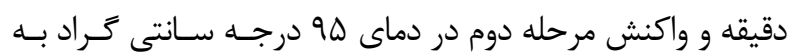

Real-time-PCR

Lightcycler96-Roche ميزان بيان زنها به وسيله دستخاه اندازه گيرى شد. ابتدا مير بهاى سنتز شده با توجه به به توصيه كيت مورد استفاده، I به ·r رقيق شدند. سيس با بال
فيبروتيكى و غيرقابل انقباض) اسـت. عـواملى كـه در ارتبــاط بـا افزايش خطر ايجاد بيمارى عروق كرونر قلب هستند را مسىتـوان به سه دسته بزرگ واصلى تقسيم كرد كه شامل عوامل غيرقابـل اصلاح و تغيير (سن بالاى فأ سال در مردان و فه سال بـه بـالا

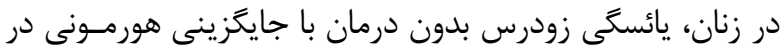
زنان، تاريخجه فاميلى بيمارى عروق كرونـر قلـب)، عوامـل قابـل

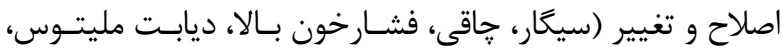

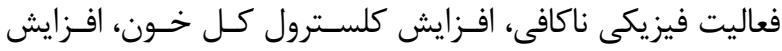
سطح كلسترول LDL، كاهش سطح كلسترول HDL)، و عوامـل

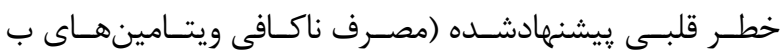
كميلكس، هييرانسولينمى) است (ه). بر اساس برخى گزارشهـا عامل اصلى انفاركتوس ميوكارد حاد تغييـر نحــوه زنــدكى اسـت

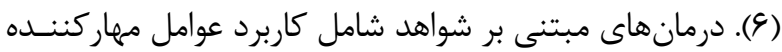
آنزيم تبديل كننده آنزيوتانسين، استاتين ها، آنزيويلاستى، تعبيـه

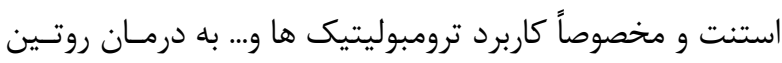

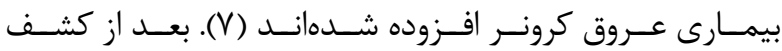
هiRNA

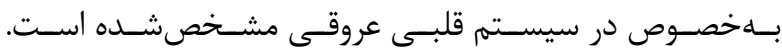

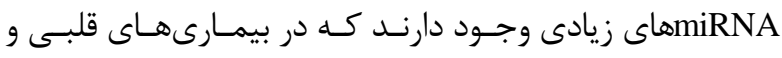

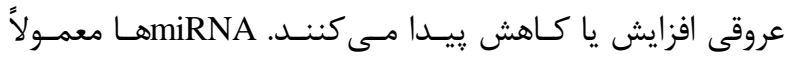
هاى هRNA (^). تاكنون بيش از · miRNA rd انسانى شناختهشدهاند (9).

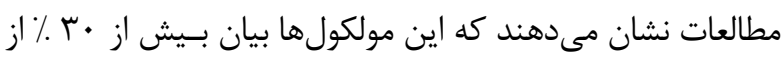
زنه هاى بنيادى را در فرايند بيولوزيكى مختلف تنظـيهم مـى كنــد. اين فرايند شامل تكثير، تمايز، مهاجرت، آيويتوز و مرگ مى بـ باشد

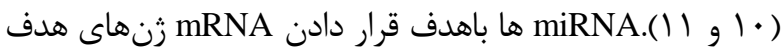
باعث خاموشى رنها مى گردند. بسيارى از فرايندهاى ياتولوزيكى

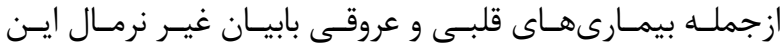

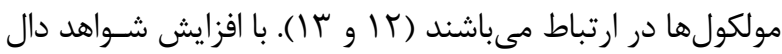

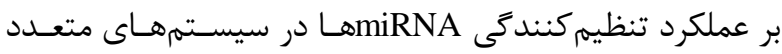
بيولوزيكى، ارزش اين مولكولها بهعنوان بيوماركرهاى تشخيصى

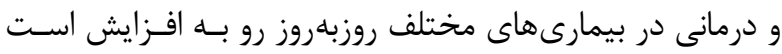

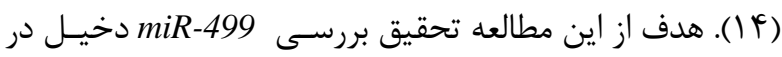
روند آيويتوز سلولهاى قلب درسرم بيماران دجار MI بود.

\section{مواد و روشها}

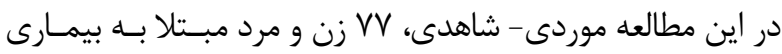
قلب و عروق با عارضه سكته قلبى (MI) با تشخيص بالينى يزشك متخصص بسترى در بيمارستان فوق تخصصى قلب شـهيد مـدنى 


\begin{tabular}{|c|c|c|}
\hline & & جدول ا. شرايط دمايى PCR \\
\hline Do & زمان & مرحله \\
\hline ه9 درجه سانتى & 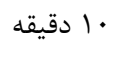 & واسرشتخى اوليه \\
\hline هو درجه سانتى گراد & 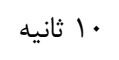 & واسرشتخى \\
\hline ع ع درجه سانتى عراد & & اتصال و گسترش \\
\hline مرحله تكثير به تعداد هأ جرخه & 9 4 ثانيه & \\
\hline
\end{tabular}

جدول r. مشخصات يرايمر هاى مورد استفاده در يزوهش

204102, hsa- miR-499-5p, LNA ${ }^{\mathrm{TM}}$ PCR primer set, UniRT miRCURY LNATM Universal RT

miR-499 microRNA PCR, microRNA primer set, 200 rxns

U6

203907, U6 snRNA (hsa, mmu, rno) PCR primer set, UniRT. miRCURY LNA ${ }^{\mathrm{TM}}$ Universal RT microRNA

PCR, reference gene primer set. NCBI Symbol U6snRNA, NCBI Accesion: x59362

دماى مرحله اتصال يرايمر در اين كيت براى تمام زنها يكسان و برابر با •و درجه سانتى گراد طبق جدول باست.

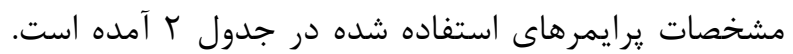

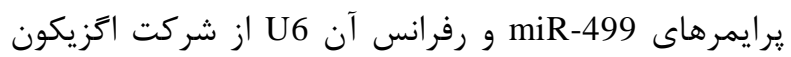
تهيه UUAAGACUUGCAGUGAUGUUU جهت تحليل دادهها از نرم افزار SPSS.version19 و t-test استفاده شد. ه • |• معنى دار در نظر كرفته شد.

\section{يافتهها}

اطلاعات دموگرافيك افراد مورد مطالعه در جدول س و منحنى ذوب در نمودار ا قابل مشاهده هستند. تاييد اختصاصى بودن عملكرد :يرايمرها و نيز عدم آلودگى به DNA

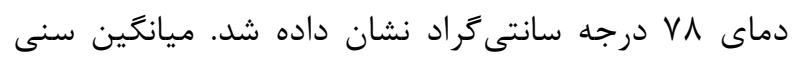
مردان و زنان گروه بيماران مورد مطالعه به ترتيب و

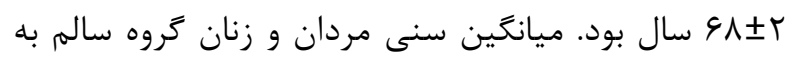

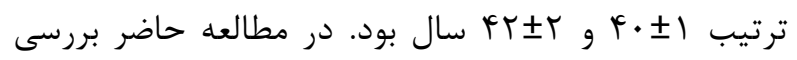

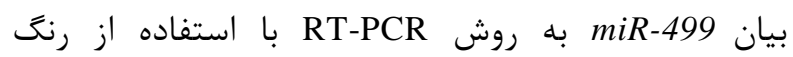
سايبرگرين انجام شد. ميزان بيان زن 499-4iR در سرم خونى افراد مبتلا به بيمارى MI و افراد سالم با استفاده از

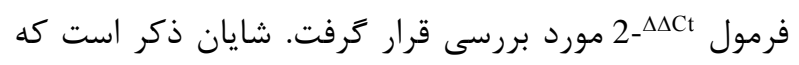

استفاده از يرايمرهاى اختصاصى اقدام به آماده سازى

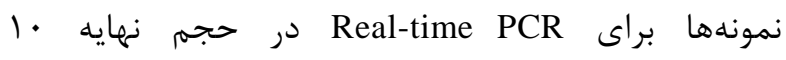

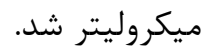
بعد از آماده سازى محلول طبق توصيه كيت با استفاده از

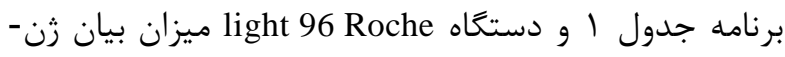
ها بررسى شد و سيس با استفاده از فرمولهct به بررسى ميزان نمونهها شد. در اين مطالعه براى حصول اطمينان از صحيح سنتز cDNA براى PCR به miR-U6 به عنوان زن كنترل داخلى انجام شد. براى نرمال سازى بيان زنها در نمونههاى كنترل بهن و تومور با توجه به اينكه يرايمرهاى مورد استفاده به صورت

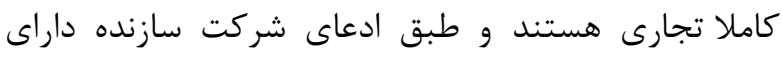
حداكثر بازدهى در طول واكنش هستند از فرمول D(target)-ct(control)ct

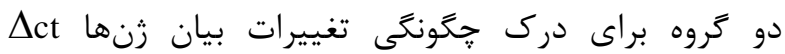

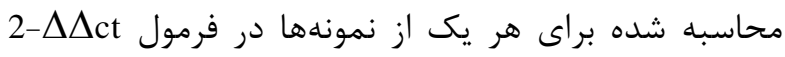
براى هر يك وارد شد تا بيان دقيق هر نمونه مشخص شود. در نهايت دادههاى حاصله در دو گروه با استفاده از روش هاى آمارى با هم مقايسه شد. با توجه به اينكه در در اين داصن مطالعه هم براى زن كنترل داخلى و هم زنهم زنهاى مورد بررسى از كيت real time ويزه micro RNA ساخت كميانى Exiqon استفاده شد كه مراحل انجام تكنيك و ورئ 
قسمت از قلب روى مىدهد (\&)). اين توقف گردش خون

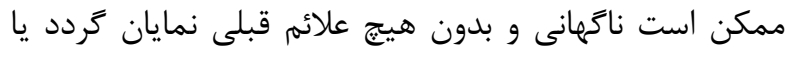
يس از קند حمله آنزينى (درد قفسه سينه) نمود يابد عمدهترين دليل سكته بسته شدن ركَهاى تغذيه كننده قلب است. سكته قلبى نوعى عارضه فراگير است كه هرساله باعث

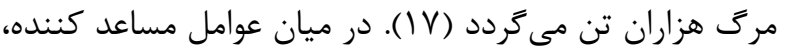
ديابت، فشارخون بالا، كلسترول خون بالان افراط الاط در در استعمال دخانيات و الكل، عدم فعاليت بدنى، فشار عصبى، سابقه فالئه فاميلى

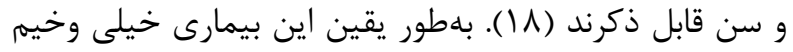

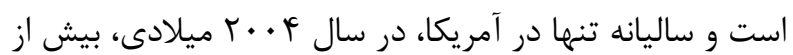

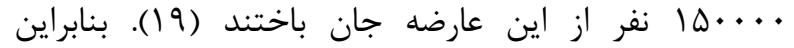

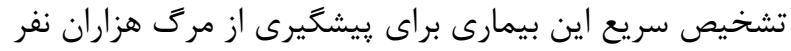

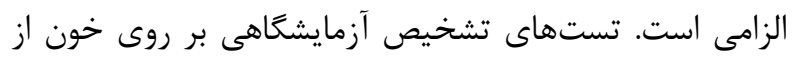

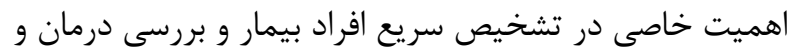
يا تعيين ريسك حمله مجدد در آينده برخوردار هستند.

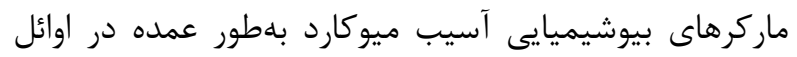
دهه • • 19 كشف شدند، از جمله آنزيمهاى ترانس آميناز كه بعدها بهعنوان GOT و GPT در عضلهى قلب شناختهشدند. در بررسى بيماران بسترى نشان داده شد كه سطح ترانس

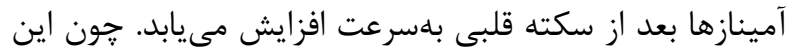
آنزيمها به مقدار كافى در عضله اسكلتى و بافتهاى ديكر نيز

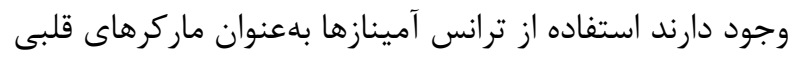

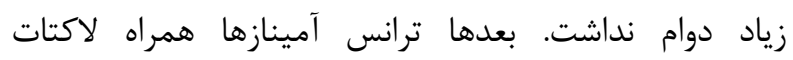
دهيدروزناز و كراتين كيناز براى تشخيصهاى قلبى معرفى تراني

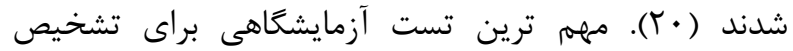

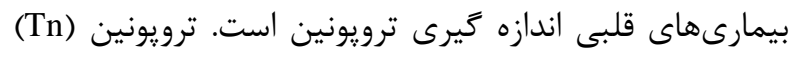

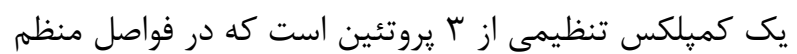
در رشتههاى نازى عضله مخطط قراركرفته است. تست آنس ايمنوشيميايى ترويونين براى بيمارىهاى قلب مىتواند

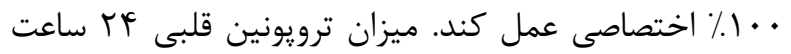

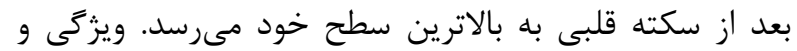
حساسيت بالاى ترويونين قلبى باعث شده است كه اين آنزيم

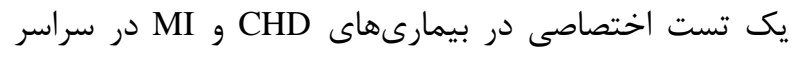
جهان در نظر كرفته شود (Iال). ازآنجايىكه سطح سرمى MI بيوماركرهايى كه براى بيمارىهاى قلبى و تشخيص

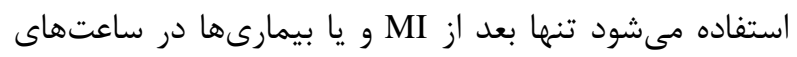

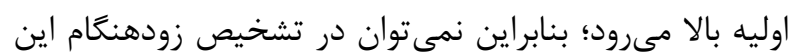
بيوماركرها را استفاده كرد. بنابراين دانشمندان به دئ دنبال ويدان

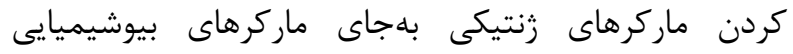

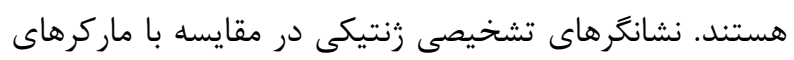

در مطالعه حاضر از زن miR-U6 به عنوان زن كنترل كننده

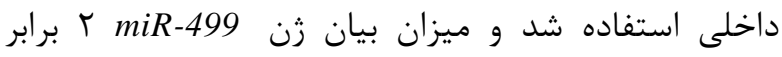

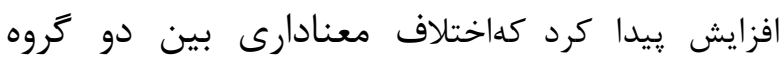

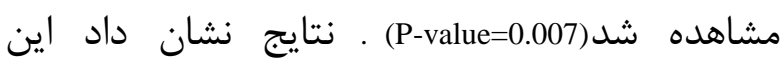
miRNA

(P-value=0.06).

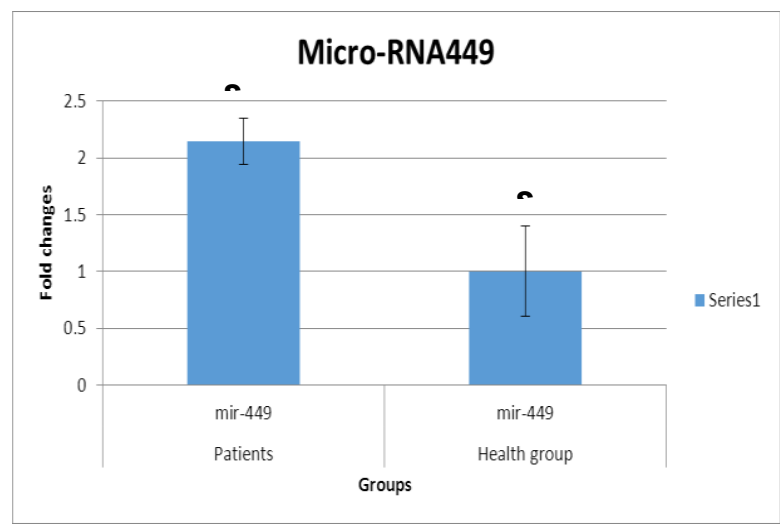

نمودار ا. بيان سطح miR-499 در خون افراد بيمارى و كنترل. همه ct هاى به دست آمده بر miR-U6 نرمالايز شده است. (P-value $=0.007$ )

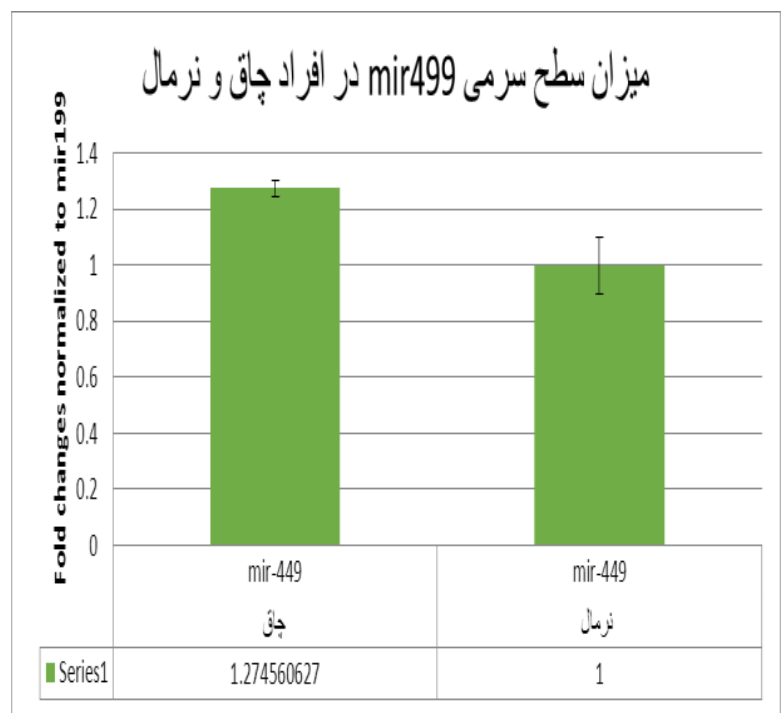

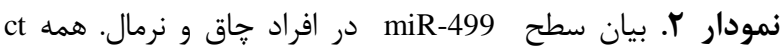
هاى به دست آمده بر miR-U6 نرمالايز شده است. $(\mathrm{P}-\mathrm{value}=0.06)$

بحث

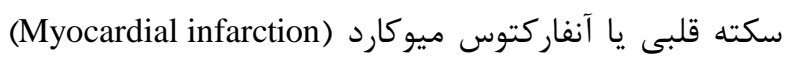
يا حمله قلبى، عبارت از انهدام و مركى سلولى دائم و غيرقابل بركشت در بخشى از عضله قلب (ميوكارد) است كه به علت آلت آلت ازبينرفتن جريان خون و وقوع يك ايسكمى شديد در آن 


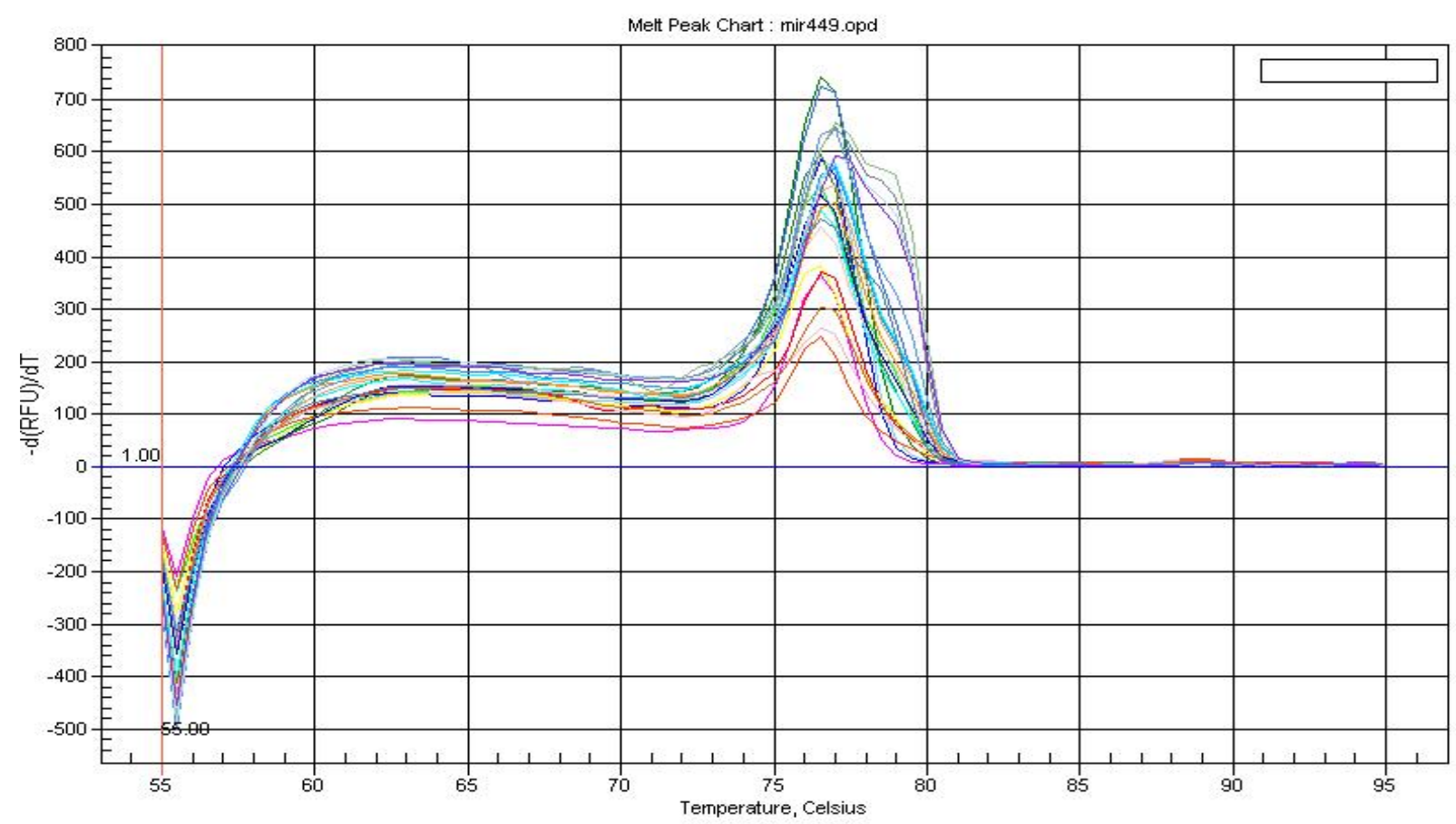

شكل ا. نمونه منحنى ذوب يِ از انجام Real Time PCR. وجود باندهاى تك نشاندهنده تكثير اختصاصى و بدون مشكل است.

مصنوعى در موشها و سيس اندازهيرى سطح سرمى انواع

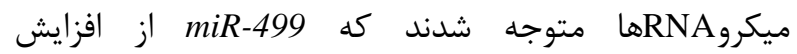

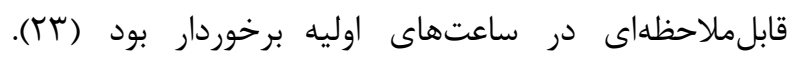

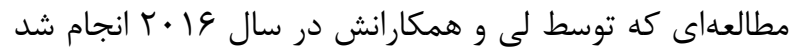

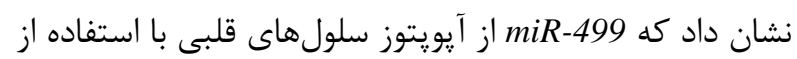

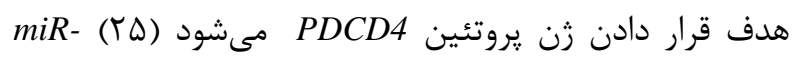
499 مىتواند تاثير مثبتى در درمان نارسايى درّين قلبى داشته باشد، البته بايد بين دست كارى رنى و تاثير فعاليت بدنى تفاوت داتئ دارئ

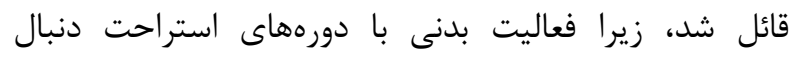

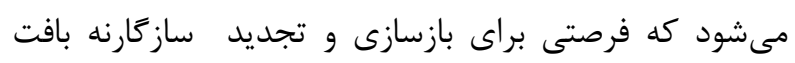

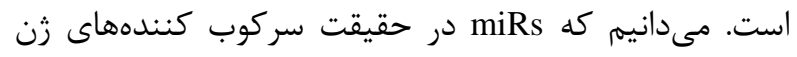

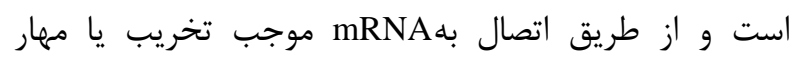

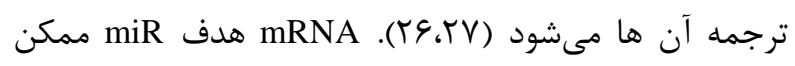

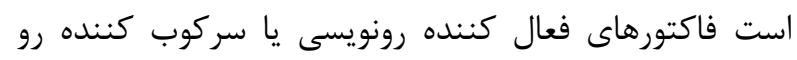
نويسى باشند كه اين mRNA را زن هدف مى نامند. از زنهاى

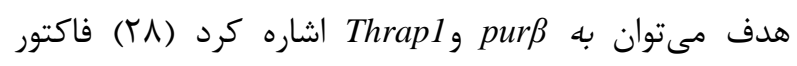
purß. miR-499 داراى يك جايخاه اتصالى براى purß mRNA3 است، به اين معنى كه اين زن توسط

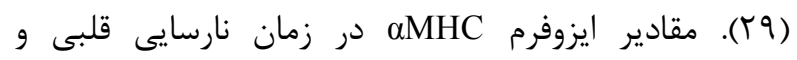

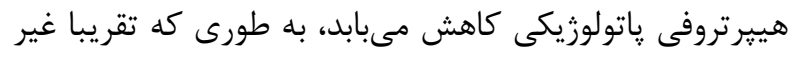

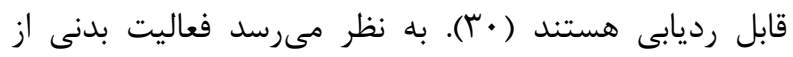

بيوشيميايى از كارايى بالايى برخوردار هستند و تشخيص

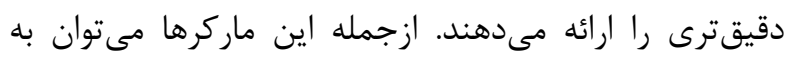

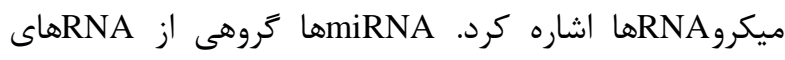

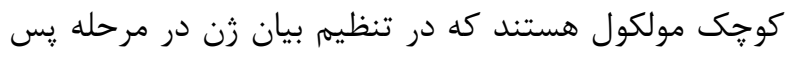
از رونويسى نقش دارند. حضور

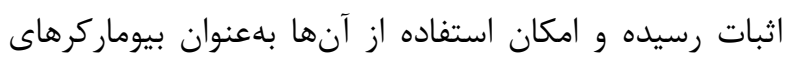

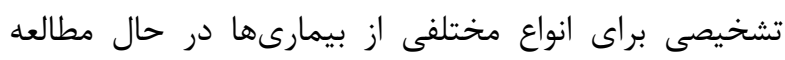

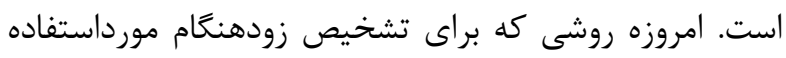

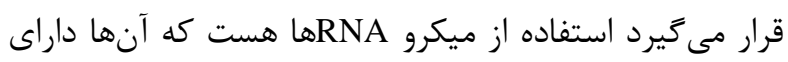

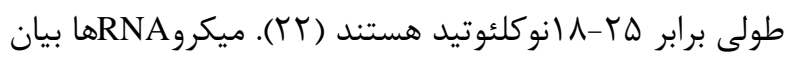
زنها را يس از رونويسى از طريق تجزيه mRNA يا مهار

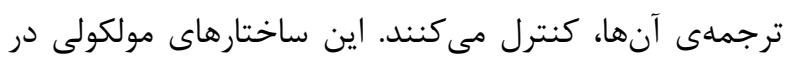
كنترل فرايندهاى فيزيولوزيك و و ياتولوزيك سنيك سلولى شركت

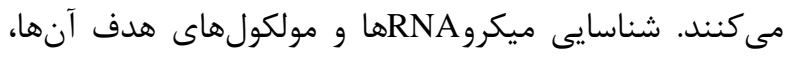
افق روشنى را براى شناخت مسيرهايى كه منجر به به بيمارىها

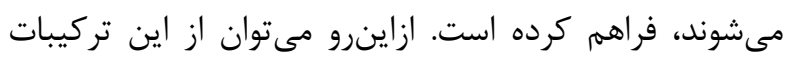

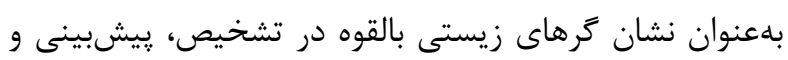

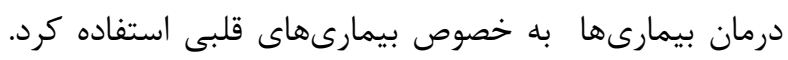

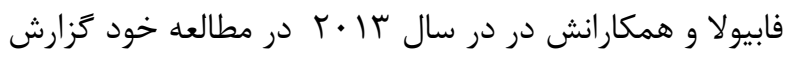

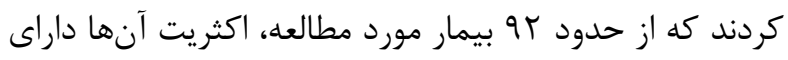

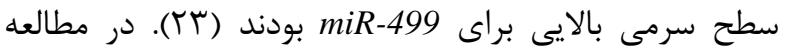

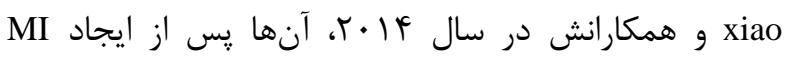




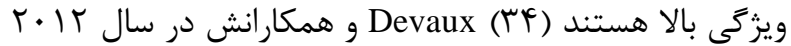

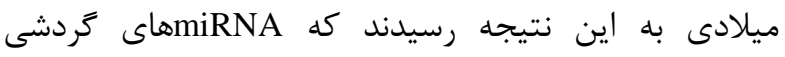
نشانكرى قدرتمند براى انفار كتوس ميوكارد حاد هستند (هَّ).

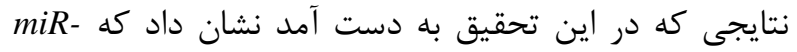

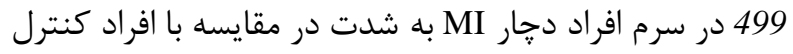

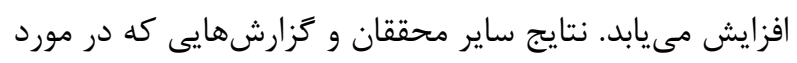

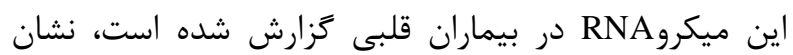
مى دهد مطالعه حاضر با بسيارى از آنها منطبق است.

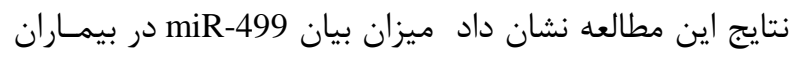

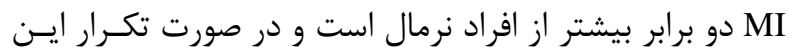

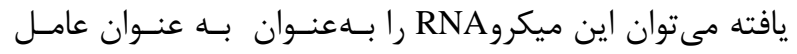

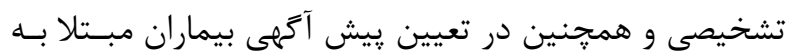
MI به كار برد. M M و

\section{قدردانى و تشكر}

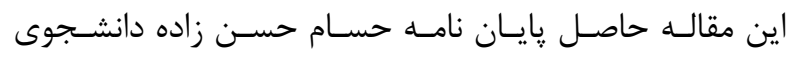

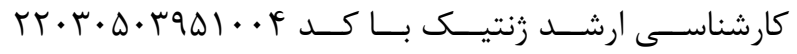

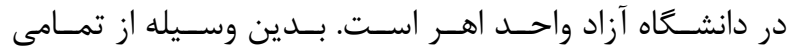

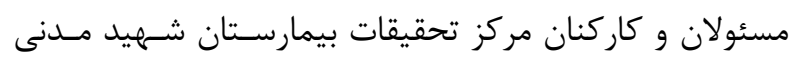
تبريز و ساير افرادى كه در انجام اين يزوهش همكارى كردنـد، تشكر و قدردانى مىشود.
طريق افزايش بيان miR-499 موجب افزايش بيان aMHC

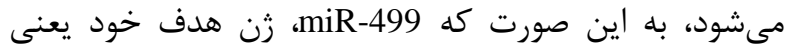

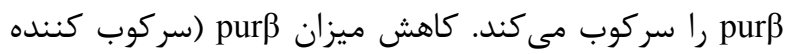

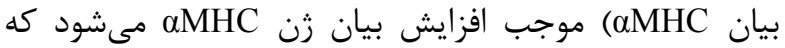
فرايندى بر خلاف آنجه است كه در هاييرتروفى نوع

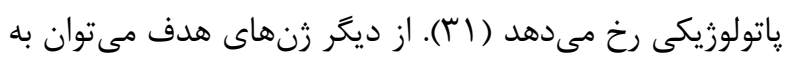
زن Thrap1 اشاره كرد كه تعديل كننده سيخنال هورمون

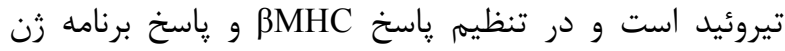
ميوفيبريل به هاييرتيروئيديسم نقش كليدى بازى مى كند

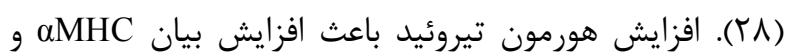

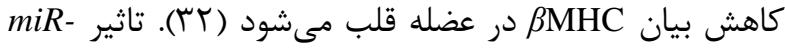
499 بر بيان زنها، با اندازه كيرى ميزان mRNA و يروتئين

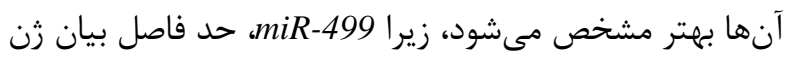
و ترجمه در سطح تروتئين آن است. Mitchelson و همكارانش در سال ها •r ميلادى به اين نتيجه رسيدند كه

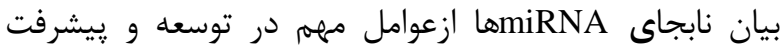

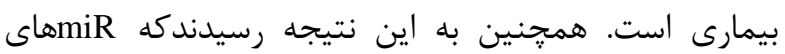
متعارف قلبى (miR1-133-206) مركزى براى توسعه و سلامت عضلات اسكلتى و قلبى يُتانداران هستند (rس).Sheikh و همكارانش در سال با •T ميلادى به اين نتيجه رسيدند كه

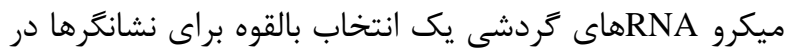

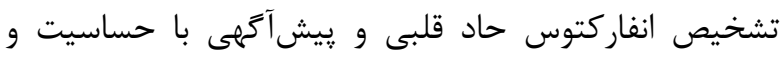

\section{REFERENCES}

1. Last J, Cummigs S. One year survival in acute myocardial infarction. Lancet 1993;341:72-5.

2. Antman EM, Braunwald E. Acute myocardial infarction. In: Braunwald E, ed. Heart diseases. $5^{\text {th }}$ ed. philadelphia: WB Saunders; 1997. P.1184-288.

3. McMechan SR, Jennifer Adgey AA. Age related outcome of acute myocardial infarction. BMJ 1998;317:1334-5.

4. Peltonen M, Lundberg V, Huhtasaari F, Asplund K. Marked improvement in survival after acute myocardial infarction in middle-aged men but not in women. The Northern Sweden MONICA study 1985-94. J Intern Med 2000;247:579-87.

5. Verderose J. Coronary Heart Disease, Nutrition management for older Adults, monograph on the internet. New York: American Heart Association; 2001.

6. World Health Organization. Technical report series 894. Obesity, preventing and managing the global epidemic, Report of a WHO consultation. Geneva: World Health Organization; 2000.

7. Ford ES, Ajani UA, Croft JB, Critchley JA, Labarthe DR, Kotteke TE, et al. Explaining the Decrease in US Deaths from Coronary Disease,1980-2000. N Engl J Med 2007;356:2388-98.

8. Garzon R, Calin GA, Croce CM. MicroRNAs in cancer. Annu Rev Med 2009;60:167-79.

9. Kozomara A, Griffiths-Jones S. miRBase: integrating microRNA annotation and deep-sequencing data. Nucleic Acids Res 2011;39:D152-7.

10. Friedman RC, Farh KK, Burge CB, Bartel DP. Most mammalian mRNAs are conserved targets of microRNAs. Genome Res 2009;19:92-105.

11. Lee Y, Ahn C, Han J, Choi H, Kim J, Yim J, et al. The nuclear RNase III Drosha initiates microRNA processing. Nature 2003;425:415-9. 
12. Williams AH, Liu N, van Rooij E, Olson EN. MicroRNA control of muscle development and disease. Curr Opin Cell Biol 2009;21:461-9.

13. Calin GA, Croce CM. MicroRNA signatures in human cancers. Nat Rev Cancer 2006;6:857-66.

14.Esau CC, Monia BP. Therapeutic potential for microRNAs. Adv Drug Deliv Rev 2007;59:101-14.

15. Livak KJ, Schmittgen TD. Analysis of relative gene expression data using real- time quantitative PCR and the 2 (Delta Delta C(T)) method. Methods 2001;25:402-8.

16. Finkle WD, Greenland S, Ridgeway GK, Adams JL, Frasco MA, Cook MB, et al. Increased risk of non-fatal myocardial infarction following testosterone therapy prescription in men. PLoS One 2014;29:e85805.

17. Hood WB Jr, Joison J, Kumar R, Katayama I, Neiman RS, Norman JC. Experimental myocardial infarction. I. Production of left ventricular failure by gradual coronary occlusion in intact conscious dogs. Cardiovasc Res 2017;4:7383.

18. Martin SS, Khokhar AA, May HT, Kulkarni KR, Blaha MJ, Joshi PH, et al. HDL cholesterol subclasses, myocardial infarction, and mortality in secondary prevention: the Lipoprotein Investigators Collaborative. Eur Heart J 2014;36:2230 .

19. Ludwig A, Lucero-Obusan C, Schirmer P, Winston C, Holodniy M. Acute cardiac injury events $\leq 30$ days after laboratory-confirmed influenza virus infection among U.S. veterans, 2010-2012. BMC Cardiovasc Disord 2015;15:109.

20. Mair J, Jaffe A, Apple F, Lindahl B. Cardiac biomarkers. Dis Markers 2015;2015:370569.

21. Shah ASV, Griffiths M, Lee KK, McAllister DA, Hunter AL, Ferry AV, et al. High sensitivity cardiac troponin and the under-diagnosis of myocardial infarction in women: prospective cohort study. BMJ 2015;350:h626.

22.Olivieri F, Antonicelli R, Lorenzi M, D'Alessandra Y, Lazzarini R, Santini G, et al. Diagnostic potential of circulating miR-499-5p in elderly patients with acute non ST-elevation myocardial infarction. Int J Cardiol 2013; 167:531-6.

23. Li C, Fang Z, Jiang T, Zhang Q, Liu C, Zhang C, et al. Serum microRNAs profile from genome-wide serves as a fingerprint for diagnosis of acute myocardial infarction and angina pectoris. BMC Med Genomics 2013;6:16.

24. Xiao J, Shen B, Li J, Lv D, Zhao Y, Wang F, et al. Serum microRNA-499 and microRNA-208a as biomarkers of acute myocardial infarction. Int J Clin Exp Med 2014;7:136.

25. Li Y, Lu J, Bao X, Wang X, Wu J, Li X, et al. MiR-499-5p protects cardiomyocytes against ischaemic injury via anti-apoptosis by targeting PDCD4. Oncotarget 2016;7:35607-17.

26. Cai Y, Yu X, Hu S, Yu J. A brief review on the mechanisms of miRNA regulation. Genomics Proteomics Bioinformatics 2009; 7:147-54.

27. Maragkakis M, Alexiou P, Papadopoulos GL, Reczko M, Dalamagas T, Giannopoulos G, et al. Accurate microRNA target prediction correlates with protein repression levels. BMC Bioinformatics 2009;10:295.

28. Van Rooij E, Quiat D, Johnson BA, Sutherland L B, Qi X, Richardson JA, et al. A family of microRNAs encoded by myosin genes governs myosin expression and muscle performance. Dev Cell 2009;17:662-73.

29. Miyata S, Minobe W, Bristow MR, Leinwand LA. Myosin heavy chain isoform expression in the failing and nonfailing human heart. Circ Res 2000;86:386-90.

30. Weiner RB, Baggish AL. Exercise-induced cardiac remodeling. Prog Cardiovasc Dis 2012;54:380-6.

31. Gustafson TA, Markham BE, Morkin E. Effects of thyroid hormone on alpha-actin and myosin heavy chain gene expression in cardiac and skeletal muscles of the rat: Measurement of mRNA content using synthetic oligonucleotide probes. Circ Res 1986;59:194-201.

32. Van Rooij E, Sutherland LB, Qi X, Richardson JA, Hill J, Olson EN. Control of stress dependent cardiac growth and gene expression by a microRNA. Science 2007;316:575-9.

33. Mitchelson K, Wen-Yan Qin. Roles of the canonical myomiRs miR-1, -133 and -206 in cell development and disease. World J Biol Chem 2015;6:162-208.

34. Sheikh Md SA, Xia K, Yang TL, Peng J. Circulating microRNAs: a potential role in diagnosis and prognosis of acute myocardial infarction. Dis Markers 2013;35:561-6.

35. Devaux Y, Vausort M, Goretti E, Nazarov PV, Azuaje F, Gilson G, et al. Use of circulating microRNAs to diagnose acute myocardial infarction. Clin Chem 2012;58:559-67. 